\title{
HOUSING AFFORDABILITY WOES AND THE STATE OF DEVELOPED UNDERDEVELOPMENT IN PENANG ISLAND
}

\author{
KHOO SUET LENG \\ NOR MALINA MALEK \\ SUZIANA MAT YASIN \\ Department of Development Planning and Management \\ School of Social Sciences \\ Universiti Sains Malaysia
}

\begin{abstract}
Housing affordability is a critical issue in Malaysia. This issue is doubly challenging in states like Penang where its topographical make-up is divided into a mainland and an island. The dwindling stock of land in Penang Island has inevitably pushed up house prices. To compound this problem, a combination of policy and socio-economic changes has collectively hiked up the cost of buying a house on the island. This has hindered equal opportunities towards home ownership. Based on a development perspective, this paper attempts to contextualize current housing woes in Penang Island. This paper argues that Penang Island's physical urban environment has 'developed' in terms of aesthetic values and appreciated in monetary terms but actual development in terms of a person's 'capability to function' and enjoy a better quality of life is not progressing in tandem. A critical state of developed underdevelopment is currently unfolding on the island in terms of housing affordability. The recommendations of this paper will contribute towards shaping pragmatic housing policies.
\end{abstract}

Keywords: Housing affordability, Home ownership, Penang Island, Quality of life, Capability to function.

\section{Introduction}

In recent times, housing affordability is increasingly becoming one of the most critical developmental issues. Apart from food and clothes, a decent roof above one's head is the third basic necessity that man should have. Thus, being deprived of home ownership can be regarded as a form of deprivation and violation of human rights. A society or a nation cannot claim to be fully developed if a huge proportion of its citizenry are faced with problems of home ownership. To exacerbate the problem, studies have shown that this is a universal problem not only in the developed world but in developing countries like Malaysia as well (Bakhtyar, Zaharim, Sopian \& Moghimi, 2013; Shuid, 2010). This then triggers one to ponder whether housing affordability woe is an impending problem and a price to pay when a nation progresses and becomes more developed. Worse still, the issue of housing affordability tends to worsen as elements of modernization such as industrialization, urbanization and gentrification set in. Put simply, there is a hefty price to pay for modernization when dynamisms of uncontrollable rural-urban migration and indiscriminate urbanization have created a contestation of space in urban areas which inadvertently hike up the cost and value of land. Basic economics will connote a situation where a limited supply of land for the construction of homes will now pose an issue and trigger an upsurge of all property prices beyond the boundaries of affordability especially by the middle and lower classes. 
Currently, the state of Penang (in Malaysia) mirrors this global trend, but in a more alarming fashion. This is because Penang Island is an island where land is limited but the demand for homes is always on the rise due to the state's 'pull factor' as a preferred locale for industrialization which, in turn, creates bountiful employment opportunities and investment. Additionally, the island city of Penang boasts yesteryear's heritage as well as state-of-the-art built environment and lifestyles. These appealing attributes are attracting people to the island. Singularly or collectively, these factors have created a set of 'real', but at the same instance produced some rather 'artificial' housing affordability issues for Penang.

Against this backdrop, this paper attempts to dissect, connect and contextualize existing housing affordability woes in Penang within the development discourse. Most previous studies have deliberated housing affordability issues by looking at the general overview of the situation in Malaysia (Hashim, 2010) or in specific Malaysian states like Selangor (Suhaida, Tawil, Hamzah, Che-Ani \& Tahir, 2010), Penang and Johor (Gapor, Malek \& Husin, 2011), However, there is a dearth of studies that explore housing affordability from a development perspective. Hence, this paper attempts to fill this research gap. Significantly, this paper will position the issue of housing affordability within the broader development discourse and then critically analyze how the meaning of development has been perceived and construed within the context of Penang Island's housing affordability.

In brief, the paper is organized into five main sections. The first section introduces the paper by setting up the problem statement and background. Subsequently, section two reviews all key literature that are related to this topic whilst section three briefly outlines the methodology. Section four discusses all the key findings and the final section concludes by providing some recommendations and implications to shape pragmatic housing and development policies in Malaysia.

\section{Literature Review}

\section{Dissecting Housing Affordability from a Development Perspective}

Housing affordability is not just any socioeconomic issue that can be addressed by merely raising income levels. Neither can housing affordability woes be solved by just allocating to lower income earners 'affordable houses' that are poorly designed, poorly located and cannot be called homes. Clearly, housing affordability is certainly not an easy issue with a quick solution. It is a development issue that requires a holistic and sustainable solution. To achieve this end, we begin first by revisiting and unpacking the meaning of development and poverty to see how these concepts are linked to housing affordability.

The concept of development has been slippery, confusing and widely contested for the past several decades (Peet \& Harwick, 2009). Along the way, development has taken on various meanings and diverse connotations as the concept was shaped and influenced by the development paradigm of that particular era. Traditionally, development was very much focused on quantifiable growth in terms of a nation's economic growth of income per capita to facilitate a country to grow its output faster than the growth rate of its population (Todaro \& Smith, 2011). At that juncture, development was perceived to be as an 'economic phenomenon' where gains in overall and per capita GNI growth are thought to be able to trickle down to the masses by providing employment and other forms of economic opportunities. Concerns pertaining to poverty, discrimination, rights and marginalization were rarely in the equation. However, in the 50s and 60s when such material (economic) growth failed to translate into better lives with clear telltale signs of societal dysfunction in the form of poverty, inequality and unemployment that still raged across all strata of society. Hence, there was a dire need to revisit and look at what development actually means. In quoting Dudley Seers (cited in Todaro \& Smith, 2011): 
The questions to ask about a country's development are therefore: What has been happening to poverty? What has been happening to unemployment? What has been happening to inequality? If all three of these have declined from high levels, then beyond doubt this has been a period of development for the country concerned. If one or two of these central problems have been growing worse, especially if all three have, it would be strange to call the result "development" even if per capital income doubled.

Clearly, when there is still no panacea to sort out and solve problems related to poverty, unemployment and inequality, a nation cannot be considered to be developed at all. Worse still, when poverty persists due to prolonged unemployment or inequitable distribution of wealth, other related issues such as the ability (and inability) to fulfill housing, healthcare and education needs will come to the fore. In the context of housing, specifically the housing affordability issue is inadvertently influenced and shaped by poverty. However, poverty by itself is no longer a uni-dimensional concept that merely concentrates on a person's lack of monetary resources (van der Berg, 2001). The poverty concept has evolved and expanded to become multi-dimensional and multi-faceted in nature. The way poverty is now being defined is concomitant to how development has earned a fresh conceptualization in contemporary development discourse.

For instance, UNESCO has neatly delineated and differentiated the various types of poverty. Extending from UNESCO's definition, we discuss the two main types of poverty, namely absolute poverty and relative poverty in relation to housing. 'Absolute poverty' is measured by the financial resources needed to meet basic needs such as food, clothing and shelter (van der Berg, 2008). Thus, individuals who are categorized as poor in absolute terms, would lack the financial resources to have a decent roof over their heads. In this regard, they are denied of their basic rights since housing is one of the three basic human necessities. The concept of absolute poverty, however, does not look at issues pertaining to quality of life or the general situation of inequality in a society.

Moving away from pure economics that define poverty by just referring to quantitative indicators such as a nation's poverty line, the emergence of the concept of 'relative poverty' is important and relevant given that individuals have their social and cultural needs and demands too. Thus, relative poverty is defined as poverty when associated to the economic status of other citizens in a society. As purported by van der Berg (2008: 10), relative poverty is a form of poverty that is ascertained by the society where a person lives. For example, an individual is considered poor if he/she lives below existing standards of living in a particular societal context. ${ }^{1}$ In housing for example, an individual who is financially sound enough to own a house in the village might be too poor even to rent a room in the urban area.

To delve deeper, scholars like Amartya Sen (1999a, 1999b) have further expanded the comprehension of poverty by defining it as a condition that occurs when a person is denied the freedom to choose, and subsequently shape his/her capability to function effectively in a particular society (see also Todaro \& Smith, 2011). This notion of poverty is in line with the United Nation's statement that views any form of denial of choices and opportunities to be a form of poverty and violation of human dignity, and thus, affect an individual's ability to function effectively in a society. Clearly, this multidimensional portrayal of poverty gravitates far beyond the meaning of poverty as being solely associated to a shortage of monetary resources. Based on Sen's perspective, the multidimensional nature of poverty suggests

\footnotetext{
Poverty extracted from UNESCO's website, (Available at http://www.unesco.org/new/en/ social-and-human-sciences/themes/internationalmigration/glossary/poverty/) (accessed 18 March 2015).
} 
that inadequate or unaffordable housing can be perceived as a form of poverty by itself. Thus, new forms of poverty have emerged such as 'education poor', 'transportation poor' and in this case, 'housing poor.'2

Concomitantly, Sen also purports and introduces the three core values of development, namely sustenance, self-esteem and freedom to choose. These three values will form the conceptual basis for this paper. Firstly, a person should live in a society that enables and facilitates sustenance, in this case, a decent home. Subsequently, anyone who has the economic means to own a house will be able to earn the self-esteem and enjoy the pride that comes along with home ownership. To be able to own one's home is a basic necessity and right that should not be compromised or deprived at any cost. To truly enjoy this right, individuals ought to be given the freedom to choose where they live and what types of houses they desire. Only then can we claim that a society/nation has fully developed in which improvement to a society takes place in a holistic, balanced and sustained manner where good and affordable housing is enjoyed by citizens from all strata of society to ensure a better quality of life. The importance of housing was also resonated by the United Nations Centre for Human Settlement (UNCHS) during the Declaration on Cities and Other Human Settlements in the New Millennium with a major goal to provide adequate shelter for all especially those in developing countries. The next section will dissect the meaning of housing affordability.

\section{What is housing affordability?}

Albeit a broadly used concept, the actual meaning of housing affordability has been widely contested in recent years. For instance, in the United States since the 1970s, affordability has been indicated based on the percentage of income spent on housing whereas in the United

2 Poverty extracted from UNESCO's website, (Available at http://www.unesco.org/new/en/ social-and-human-sciences/themes/internationalmigration/glossary/poverty/) (accessed 18 March 2015).
Kingdom, housing affordability encompasses a broader spectrum that includes housing supply, housing needs and housing costs (AHURI, 2005). This concept of housing affordability was conventionally linked to lower income households that required assistance to allow them to gain home ownership without having to bear undue financial hardship (URC 2008: 5). Through the years, 'affordable housing' has emerged as a preferred alternative to terms such as 'public', 'social' or 'low cost' housing (AHURI, 2005). Perhaps one of the most aptly defined conceptualizations of housing affordability can be referred to Maclennan and Williams' (1990) (cited in AHURI, 2005) depiction as follows:

'Affordability' is concerned with
securing some given standard of
housing (or different standards)
at a price or rent which does
not impose, in the eyes of some
third party (usually government),
an unreasonable burden on
household incomes.

Despite the above discrepancies in definition, a review of key literature points to the continued popularity and applicability of the 30/40 affordability rule that stipulates that housing costs should be less than 30 per cent of the gross household income for the bottom 40 per cent of the household income distribution (AHURI, 2005; URC 2008). However, this ratio approach of measuring the relationship between household incomes and housing costs has also attracted many critiques given that incomes and costs change over time and the proportion of disposable income for lower-, middle- and high-income households differ considerably (URC, 2008). Scholars have further expanded and redefined the capability of a household to buy a house into three diverse concepts of affordability, namely purchase affordability which looks at the ability of a household to secure sufficient funds to purchase a house, repayment affordability that weighs the burden imposed on a household to pay their monthly mortgages, and finally income affordability which is the classic ratio approach that measures the ratio between 
house prices and income (Gan \& Hill, 2009). Nonetheless, the ratio approach is still a widely used indicator to signal the affordability level of a household.

Gauging from the burgeoning literature on housing affordability in both the developed and developing worlds, it can be argued that this is indeed a universal problem that does not as yet have a solution. In fact, housing affordability is now viewed as a $21^{\text {st }}$ century problem for most countries (AHURI, 2007). Technical reports and blueprints from developed countries like the United Kingdom, New Zealand and Netherlands have all pointed to one similar trend - housing that is no longer affordable not only for lower income families and the working class but also the emerging middle class of young adults who have just entered the workforce. For example in the UK, the hike in house prices have escalated so drastically that despite having real growth in income, the new generation of young Britons are unable to afford more and better housing in the way they can afford other items such as better cars or food as they get richer (Evans \& Hartwich, 2005). A British report highlighted that albeit an increase in income, it was insufficient to counter the drastic hike in land prices that, in turn, caused a drastic upsurge in housing prices. This was due to restricted supply of land which forced up the price of land and houses. However, to match and equalize demand with supply, the British planning system has resorted to allocating land for high density developments to accommodate rising demands. Eventually, market forces have equilibrated the supply and demand of the unit of houses and at the same time pitched at a price level that is high by absolute and relative terms (Evan \& Hartwich, 2005). Based on the economics of planning, undeniably, the supply of land can be regulated but the planning system is unable to control demand. It then follows that even if people demand for larger houses with higher incomes, the British planning system only allots land for small houses in high density developments. The report argues that even if the right numbers of small houses are supplied the prices will be hiked up. Worse still, if the system underestimates the units of households whereby a shortage of houses occur, the prices of houses (despite their small size) will escalate even higher (Evan \& Hartwich, 2005).

The above housing scenario is not unique only to Britain but it is now an alarming global phenomenon in both developed and developing countries alike. In fact, other developed nations like Australia and New Zealand are also mirroring this disturbing global phenomenon. For example, a recent policy paper has a title that speaks volume and says it all: 'Priced Out. How New Zealand lost its housing affordability' - which debated and touched on the increasing challenge and inability of New Zealanders to embark on the ladder of home ownership, particularly those in the lower income bracket (Bassett \& Malpass, 2013).

On the Malaysian front, housing is also assuming prime importance in the nation's development agenda. For instance, the formulation of the Malaysian National Housing Policy aims to provide a clear direction for all stakeholders in terms of planning and development of housing in Malaysia. Housing is certainly a crucial and essential element in life. The opening paragraph in the Housing Policy succintly drives home the key point. Indeed, every individual cannot be deprived of acquiring proper housing which is a basic need that can enhance the quality of life. The main emphasis of the blueprint highlights the need to provide 'adequate, quality housing at affordable prices' and also ensure the 'suitability of locations and conduciveness of the living environment,' which coincidentally run parallel to the Fourth Strategic Thrust of the Tenth Malaysia Plan. The need to provide affordable housing to every household in Malaysia is again highlighted in Malaysia's latest 5-year development plan (i.e. the $11^{\text {th }}$ Malaysian Plan).

\section{Housing affordability in Penang Island - A brief overview}

Penang State is located at the northwestern part of Peninsular Malaysia. The state consists of the island of Penang (approximately 292 sq. $\mathrm{km}$ ) and a long rectangular-shaped strip of land (approximately 739 sq. km) on the mainland called Seberang Perai. Though island studies 
literature has often highlighted the marginalized treatment and peripheral role assumed by islands (Turvey, 2007; Briguglio, 1995), this cannot be generalized for Penang State. In fact, the opposite holds true for the state where Penang Island has all along taken on the dominant role, overpowering its mainland counterpart Seberang Perai from all angles of development (Khoo, Samat, Badarulzaman \& Dawood, 2015). Despite possessing only one third of the land area compared to Seberang Perai, the population of Penang Island is rather high. In 2012, Penang Island boasted a population size of 738,500 people vis-à-vis the mainland with a population of 872,600 in the same year.This simply shows that Penang Island is more densely populated than the mainland.

Correspondingly, data on the population density in 2010 shows that Penang is ranked second has after Selangor with a high population density. Penang's population density increased from 860 to 1,451 per sq. $\mathrm{km}$. between 1980 and 2010. In fact, the most populated area in the Northeast District with 4,293 persons per square kilometer is located on Penang Island. The state's vibrant economic activities have attracted migrants from other states to come and settle in Penang. According to the 2009 Migration Survey Report, during the period 2007 to 2009 , Penang recorded the highest number of migrant population followed by W.P. Putrajaya and Kedah (Department of Statistics Malaysia, 2010). This situation has made Penang Island diverse in terms of economic and cultural aspects which, in turn, could generate prosperity and also incidences of poverty. Without doubt, the rise in Penang's population contributes to issues of house ownership. According to Penang's Real Estate Market Report, the total supply of residential properties in the third quarter of 2013 was 370,000 units of which $54 \%$ was on the island and $46 \%$ on the mainland ${ }^{3}$. This scenario is attributable to the fact that the island is by comparison a more promising and viable site for employment opportunities, entrepreneurship and also other forms of wealth accumulation.

3 Penang Real Estate Market Research Report Q1 2014, (Available at http://www.henrybutcherpenang. com/upload_files/621/HB\%20market\%20report. pdf) (accessed 30 April 2015).
Consequently, such income and capital-generating avenues have accorded the island with more advanced and modern forms of livelihoods, lifestyles and consumption patterns.

Generally, diversity in the population trend indicates changes in the economy (Riche, 2000). Increasing population, including immigrants, is identified as a factor that contributes towards the issue of affordable housing. A recent study on population density impact illustrated that population density has a positive relationship to housing prices and also the stock of housing (Miles, 2012). For instance, Miles (2012) advocates that population density has been associated with the interplay of the real price of a unit of housing to the supply of housing unit based on four conditions as follows:

1. The real price of a unit of housing tends to be higher in more densely populated countries.

2. With growing population and incomes, the rise in real house prices is faster in densely populated countries.

3. The elasticity of the supply of housing is lower in densely populated countries and so is the rise in the stock of housing for a given rise in demand.

4. The amount of housing rises in less densely populated countries.

Source: Miles, 2012,

In the context of Penang, evidently, the rate of population and income growth between Penang Island and the mainland is vastly different with a higher population and income growth on the island. As a result, socio-economic imbalances and spatial inequality exist between the island and the mainland and this disparity does not augur well for the entire state as a whole. A critical issue in point is related to the availability and accessibility of affordable housing in the island. Albeit socio-economically more advanced than the mainland, Penang Island's limited and dwindling land supply is posing a huge problem in terms of providing sufficient housing for dwellers who still aspire to live on the island rather than the mainland.

For instance, recent reports by the State Government's think tank, Penang Institute, 
highlighted that Penang Island's housing scenario is increasingly unaffordable nowadays. From 2005 to 2010, Penang houses have inflated beyond the growth in real income. During that period, the average house price in Penang had escalated by 53.9 per cent and this hike was predominantly caused by property on the island. Comparatively, most types of properties are reportedly between 2 and 8 times more exorbitant on the island than the mainland which, in turn, causes the island to be more expensive (Penang Institute, 2011a). This, of course, impacts on the livelihoods, consumption patterns and well-being of the islanders. It is a dialectical situation where islanders are now confronted with a situation where the terminology 'housing affordability' is no longer confined to only low income individuals/households but the issue is rapidly becoming broad-based and inflicting the middle class even though their income levels are way above the national poverty line. At this juncture, arguably, the housing affordability issue in Penang Island is a problem of the masses affecting the poor, the low income and also the middle class that are evolving and morphing to be branded as the 'new poor' living in a highly industrialized, modernized and urbanized Penang Island that we have today. Undoubtedly, more affordable houses located on mainland Penang can be perceived as a strategy to alleviate housing affordability issues encountered by Penangites who work in Penang Island, but the longer commuting time required to cross the bridge or using the ferry services will incur in other forms of issues such as stress caused by a longer commuting time which will impact negatively on one's overall wellbeing and quality of life. Furthermore, commuting between the island and the mainland is only viable for those who own proper transportation. Subsequently, the following sections in this paper will briefly outline the methodology and then discuss housing affordability vis-à-vis the positions and plights of these categories of Penangites.

\section{Methodology}

The novelty of this paper lies in the use of content analysis to flesh out the woes of unaffordable housing in Penang Island. In this regard, content analysis is deemed appropriate for this topic since this technique is very relevant and applicable for research questions that address voluminous fragmented text with contents that are difficult to document or observe casually (Neuman, 2011). Based on content analysis, the researchers sieved through all relevant literature and discourses that are related to this topic. The use of content analysis is well justified since there is already a corpus of ready information in the form of Government blueprints, technical reports, working papers, academic documents as well as extensive media coverage on this highly popular and widely debated topic. For instance, Penang Institute which is the research arm and think tank of the Penang State Government has produced several key publications on the housing scenario in Penang which are used as key baseline references for this paper.

Besides that, reference is also made to the broader national level policies on housing like the Malaysian National Housing Policy and the PR1MA (Skim Perumahan Rakyat 1Malaysia) which are Government initiatives to provide affordable homes for all Malaysians especially those in the lower income groups. Additionally, materials from past workshops, presentations, seminars and conferences were analyzed and referred for the purpose of this paper. As mentioned earlier, although there are existing reports and publications by Government agencies (i.e. the Ministry of Housing and Local Government, Penang Institute, etc.) in terms of housing development in Malaysia, more specific research to explore housing affordability from a development viewpoint is still largely absent. Next, the following sections will discuss the findings pertaining to housing affordability woes in Penang Island before concluding the paper.

\section{Findings and Discussion}

\section{The rise of the 'new poor' phenomenon in Malaysia and its impact on home ownership}

The rapid pace of development in Malaysia has, without doubt, facilitated the emergence of 
sizeable middle-income households or popularly known as the middle class. Broadly, this category of Malaysian citizens are characterized as those with higher educational attainment, labeled as 'white collar employees' and their income level is way above and surpasses the National Poverty Line of the country (i.e. RM930). According to conventional measures of poverty, those with income levels above the National Poverty Line are not considered poor. Thus, the middle class are categorically not poor in the literal sense. However, this class of Malaysians is poor in a relative sense given that the (urban) settings or circumstances that they are currently in will deny them from commanding the type of purchasing power that is being enjoyed by their rural counterparts.

The plights of Malaysia's middle class were recently highlighted in a local daily 'The Star.' ${ }^{4}$ Their positions are not enviable given that they assume a 'squeezed middle' position between the working class and the upper class in contemporary Malaysian society. Their plights were highlighted by the Penang Institute Chief Executive Officer Dr Lim Kim Hwa when he lamented that it is increasingly challenging and difficult for middle-income households to cope with healthcare and to afford homes that are within their affordability. To compound the problem, prominent Malaysian scholars like Datuk Abdul Rahman Embong from Universiti Kebangsaan Malaysia's Institute of Malaysian and International Studies have affirmed the fact that more than half of Malaysia's population are now classified as the middle class ranging from administrators, managers and professionals with incomes between RM10,000 to RM30,000 monthly to semi-professionals like technical and clerical workers earning around RM2,000 to RM4,000 monthly. The question and concern that come to fore are the actual affordability level and purchasing power of this category of citizens which, in turn, dictate the quality of life

$4 \quad$ The squeezed middle, Business News, The Star Online, (Available at http://www.thestar.com. my/Business/Business-News/2014/12/20/Thesqueezed-middle-Without-integrated-policies-tohelp-them-tackle-the-rising-cost-of-living-thesa/?style=biz) (accessed 28 April 2015). and well-being that they experience and desire to have.

This situation is doubly challenging in urban settings like Penang Island where the cost of living is very high. It is basic logic and simple arithmetics when a substantial portion of a person's disposable income has to be allocated for daily sustenance-related necessities such as food, transportation and such, hence, the remaining portion left for purchasing capital assets such as houses will be significantly reduced. In this regard, a middle-income earner in Penang will face the vagaries of not being able to afford and enjoy the type of desired housing in terms of design, quality and location. Being trapped in a situation of relative housing poverty, Penang in specific, and Malaysia in general, is now witnessing the rise of the 'new poor' which refers to the nation's substantial middle class who are not classified as poor in absolute terms given that their income levels are way above the National Poverty Line. However, their inability to live well and enjoy a better quality of life like owning a decent house in a highly competitive and pressing environment have casted them in the 'relative poverty' category. In specific terms like those used in developed economies, Penang is now witnessing the rise of this category of middle class known as the 'new poor.' Also known as the "sandwich class," the new poor finds it difficult to make ends meet, prepare for retirement and yet their income levels exclude and make them ineligible for most social assistance. This point was also resonated by local scholars like Universiti Malaya's Dr Lee Hwok Aun from the Department of Development Studies who pointed out even the Government's affordable housing scheme, PR1MA, is not within the reach of fresh graduates. ${ }^{5}$

Although major cities like Hong Kong, Beijing and New York currently have a strong rental market where urban dwellers opt to rent rather than

\footnotetext{
$5 \quad$ The squeezed middle, Business News, The Star Online, (Available at html: http://www.thestar. com.my/Business/Business-News/2014/12/20/ The-squeezed-middle-Without-integratedpolicies-to-help-them-tackle-the-rising-cost-ofliving-the-sa/?style=biz) (accessed on 28 April 2015).
} 
to own, this trend should not be the accepted as norm by all urban citizenry. Making housing affordability as an indicator of urban poor is justifiable because as argued in the above literature, poverty is no longer only measured by looking at one's income. As highlighted by Sen's comprehension and expansion of the poverty concept, a person's inability to choose the type of dream house they desire is also a form of poverty by itself. In Penang's case, although vital statistics might show that the state has high average monthly income, the inability of Penangites to own a home of their choice is in fact a manifestation of the 'housing poor'.

\section{Unbalanced house price to income ratio}

Whilst the prices of houses especially those in highly urbanized settings like Penang Island have skyrocketed beyond the means of most local Penangites, the income level of the urbanites have not increased in tandem (Penang Institute, 2011a). This situation is further aggravated by the high cost of living on the island. As argued by Stuart MacDonald (Urban Researcher at Penang Institute), the disproportionate ratio between household income and house price in Penang will lead to issues of affordability and housing stress. Based on the ratio approach that compares house price to income, Penangites who spend more than $30 \%$ of their income on housing is deemed to be under housing stress. Given the disproportionate growth between house price and income levels in Penang, it comes as no surprise that Penangites are actually forking out a percentage higher than $30 \%$ to finance their housing commitments. A situation of extreme housing stress arises when financial allotments towards housing exceed 50\% (Penang Institute, 2011a).

In Malaysia, previous housing studies (Md. Sani, 2012; Gapor, Malek \& Husin, 2011; Malek \& Husin, 2012) identified the two main determining factors of home ownership in urban areas, namely a stable source of income, and the availability of financing facility, especially in the form of housing loans provided either by the government or private financial institutions. However, high dependency on financial loans may create other social concerns, especially to urban families, as it constricts their family budget. Thus, from a development perspective, housing affordability issues should be dealt with in a more comprehensive and holistic manner. It should consider other social aspects (i.e. comfort, happiness, safety) towards the enhancement of quality of life and not merely focus on improving one's monetary ability to buy a house. The negative ramifications that result from shouldering higher housing commitments beyond one's ability will witness a situation where other aspects of personal consumption such as food, clothing, saving, healthcare and others will have to be scaled down accordingly - which in one way or another affects a person's quality of life and capacity to function well in society at large.

To exacerbate this situation, previous housing studies and voices of the 'new poor' are resonating disgruntled tones due to the uncontrolled situation of rising house prices in Penang Island (Goh, 2010). Findings have shown that landed properties in old residential areas have appreciated by leaps and bounds. For example, existing terrace houses in middle-class Island Glades are tagged at RM600, 000 and above. Similarly, new three-storey houses in George Town including those in Jelutong and Gelugor are priced at RM800,000 and beyond (Goh, 2010: 154). These are merely figures in 2010.

Currently in 2015, prices have hiked upwards in a more alarming manner. According to real estate websites like Property Guru, new threestorey houses have skyrocketed beyond the one million mark. For instance, three-storey houses in previously less developed areas like Batu Maung and Sungai Ara are selling for RM1.5 million and RM1.28 million respectively. In more upscale residential areas like Seri Tanjong Pinang developed under the Eastern \& Oriental Group, a three-storey house can range between RM2.25 to RM3 million. ${ }^{6}$

6 Property Guru website - Terrace/Link House For Sale in Malaysia, in Penang, (Available at http:// www.propertyguru.com.my/property-for-sale?limi $\mathrm{t}=10$ \&autocomplete $=\{\% 22$ objectId $\% 22 \% 3 \mathrm{~A} \% 2$ 2MY07\%22\%2C\%22objectType\%22\%3A\%22R EGION\%22\%2C\%22properties\%22\%3A $\%$ 22re gion $\% 22 \% 3 \mathrm{~A} \% 22 \mathrm{MY} 07 \% 22\}$ \} \&unselected=RE GION|MY07\&regio1n_code[]=MY07\&market= residential\&freetext $=$ Jalan + bukit + gambir $\% 2 \mathrm{C}+\mathrm{p}$ enang\&property_type_code[]=TER3\&property type $=$ T\&region_code $=$ MY07) (accessed on 6 May 2015). 
The spike in house prices implicates housing transactions. When observing the housing transaction patterns in Penang, NAPIC reported that most Penangites (i.e. 65\%) can only afford residential properties below RM400,000 which falls under the low cost and low-medium cost housing schemes. ${ }^{7}$ By contrast, only a small proportion of $18.55 \%$ of residential properties were transacted at the price range of RM500,000 to RM1 million (Refer to Table 1 below).

Table 1

Transaction by price range for the residential properties in Penang Quarter 3, 2014

\begin{tabular}{lcc}
\hline Price range $(\mathrm{RM})$ & \multicolumn{2}{c}{ Residential properties } \\
\cline { 2 - 3 } & No & $\%$ \\
\hline $0-50,000$ & 224 & 5.34 \\
$50,001-100,000$ & 512 & 12.21 \\
$101,001-150,000$ & 471 & 11.23 \\
$150001-200000$ & 411 & 9.80 \\
$200001-250000$ & 285 & 6.80 \\
$250001-300000$ & 328 & 7.82 \\
$300001-400000$ & 494 & 11.78 \\
$400001-500000$ & 381 & 9.08 \\
$500001-1000000$ & 778 & 18.55 \\
1000001 and above & 310 & 7.39 \\
Total & 4194 & 100.00 \\
\hline
\end{tabular}

Source. NAPIC, Q3, 2014

Clearly, the difference in terms of residential properties transacted between low-cost and high-cost housing indicates the imbalance and effects of a laissez faire housing market at play in Penang. No doubt the rich are willing and able to acquire properties beyond the RM500,000 price tag. However, the question that arises is with regard to the fate of the B40 or new middleincome earners to afford a comfortable house and at the same time bear the burden of high

Public housing are low-cost houses up to RM42,000 and low-medium cost houses from RM72,500 to RM400,000 on the island and from RM72,500 to RM250,000 on the Seberang, Penang State Government New Housing Rule, (Available at http://www.penang.gov.my/index. php/en/2013-04-01-05-24-50/kenyataan-akhbaryab-km/2787-penang-state-government-newhousing-rule-2013) (accessed on 25 May 2015). living cost. As argued by Stuart Mac Donald "The prices of future low cost and affordable housing transactions will not be set by the state government, and will instead be based on a 'willing buyer, willing seller' basis." 8

\section{Developers' preference to build expensive homes}

Arguably, the pervasiveness of economic globalization has not left out the housing industry, more so in the case of Penang Island. Penang, just like any other city around the globe aspires and strives to join the league of global city status and earn the label of a 'livable city.' Georgetown, the capital of Penang has been ranked the eighth

8 Penang Monthly- New Housing Policies to help Penangites cope, (Available at http:// penangmonthly.com/new-housing-policies-tohelp-penangites-cope/ ) (accessed on 25 May 2015). 
place among the top 40 holiday hot spots in the world. ${ }^{9}$ However, exhibiting such labels has its price to pay when a livable city begins to attract more and more foreign investment and be the site of capital accumulation for investors and expatriates alike. In due course, it will be a situation where capital attracts more capitalists and vice-versa. Noticeably, the shift and flow of expatriate capital into the Malaysian property industry as the sector globalizes has witnessed increased interest by local developers to shift and match their supply to meet the needs of this emerging market of foreign buyers (Soyza, 2013), the rich and returning diaspora who have accumulated wealth overseas. Eventually, it will be a dire straits situation where cost of living and property prices will increase to cater to the needs and demands of the rich instead of addressing the needs and demands of the middle and lowincome Malaysian earners.

In Malaysia, the brunt of capitalism has reared its ugly head in the form of exclusive housing schemes targeted at the rich as well as foreign expatriates via Malaysia My Second Home (MM2H) program. Clearly, the profiteering traits of housing developers will result in detrimental ramifications for local Penangites especially those in the lower rung of the income bracket. Given that they function in a laissez faire housing market with loose regulations in place, developers in Penang are literally free to build properties that will generate the highest level of profit to ensure bountiful capital accumulation. Resultantly, the laissez faire housing market in Penang Island has succumbed to market forces and leaned towards attracting and cashing in on capital at the expense of building and designing desirable houses for the masses.

At the same instance, the trend towards lifestyle concepts and higher quality specifications also influence the price hike of real estate in Penang (Henry Butcher Malaysia, 2014). Building low-

9 Theguardian. Holiday hotspots: where to go in 2014, (Available at http://www.theguardian.com/ travel/2014/jan/03/holiday-hotspots-where-togo-in-2014) (accessed on 25 May 2015). cost or low-medium-cost units are certainly not their priority nowadays. Most of these exorbitantly priced super condos are located in waterfront areas like Gurney Drive, Straits Quay, Tanjung Ferringhi and Tanjung Bungah. For instance, super condos like Gurney Paragon (with approximately 3000 sq. ft.) situated along Gurney Drive are selling at RM3,000,000 per unit. ${ }^{10}$ Similarly, the Cove luxury condominium located at Tanjung Bunga is also selling between RM2,800,00 to RM3,200,000 per unit. ${ }^{11}$ Obviously, these exorbitantly priced super condos are definitely not within the reach of the middle and low-income earners. As local researchers have pointed out, Penangites are "priced off" and increasingly being "pushed out" from prime areas to stay in the suburbs and outskirts like Batu Maung, Teluk Kumbar and Balik Pulau or even the mainland of Penang (SERI, 2010).

\section{Will State intervention help in equitable distribution of housing?}

Malaysia in general, and Penang in particular have a myriad of diverse housing aids, schemes and initiatives to help Malaysians own their first homes. Under the auspices of the Ministry of Housing and Local Government, the Malaysian National Housing Policy was formulated with the goal to provide sufficient, livable, quality and affordable housing to ensure sustainability of the quality of life of Malaysians. ${ }^{12}$ Clearly, the State in this context has a pivotal role to play in housing provision (Goh, 2010) given that shelter above one's head is indeed one

10 Property Guru. Gurney Paragon. (Available at http://www.propertyguru.com.my/condo/gurneyparagon-2135/listings/1) (accessed on 18 May 2015).

11 Property Guru. The Cove. (Available http://www. propertyguru.com.my/condo/the-cove-1848) (accessed on 18 May 2015).

12 National Housing Policy. Kuala Lumpur: National Housing Department, Ministry of Housing and Local Government. (Available at http://www.kpkt.gov.my/lain_terbitan/DRN_ KPKT_\%28ENG\%29.pdf) (accessed on 19 May 2015). 
of the three basic necessities for survival. In development parlance, the deprivation of proper housing is also perceived as a form of poverty itself - housing poor - which many Penangites especially the working class and the new poor are experiencing and encountering right now.

Whether to view housing as a social good that warrants State intervention is, arguably, the rising concern here. In our modern society today, housing has a dialectic meaning. To the rich, housing is a status symbol. Owning a myriad of housing types (i.e. landed property, highrise, shophouses, etc.) is symbolic and reflective of their wealth. On the contrary, the homeless group at the bottom billion (i.e. Malaysia's B40 which is defined as the bottom $40 \%$ household income group) would view housing as a basic need, and they would place the onus on the State to provide them with a decent roof above their heads. To the poor, their rights to housing is now being championed and advocated as a social good underpinned by the philosophy of social justice. It is when the housing market fails to allocate and redistribute the allocation of home ownership equitably between the rich and the poor, the role and function of the State is questioned and challenged. Sadly, as highlighted by scholars (Goh, 2010), Penang State has minimal power to control and regulate land on Penang Island compared to other state governments. Due to historical legacy and the unique status of land tenure (i.e. "First Grade" titles) on Penang Island, the majority of land on the island is privately owned and owners with these titles need not seek permission to change land use, thus allowing more flexibility to owners and developers to develop their land.

Hence, there are limitations upon which the State can decide upon the way land should be developed, the type of housing to be built and the market segment that developers ought to target. In this case, Penang developers have chosen to target either the wealthy expatriates or the returning diaspora with disposable cash in hand who can afford a better piece of property compared to their less financially-endowed local Penang counterparts. Undoubtedly, in Penang Island, urban neo-liberalism has been taken over by the strong presence of private capital and developers, on the pretext to further develop the island's built environment, have come up with cliched labels and connotations linking 'luxury living as the preferred way of living' to portray a high quality of urban life. However, when deliberated from a pure development viewpoint underscored by principles of holistic and balanced development, the dialectics of urban neo-liberalism has again created a fissure between the haves and the have nots. Penang Island might now boast a skyline similar to those found in developed cities like New York, Hong Kong or Sydney, but current visual aestheticisms and state of developed underdevelopment on Penang Island are not without a price to pay. When private developers only have the rich in mind, then the question of constructing and equitably allocating houses for the poor equipped with good design, located on accessible locations will then become a grave concern that has no clear solutions as yet. In turn, this concern leads us to the next contention in terms of housing and Penangites' 'right to the city', a concept popularized by French sociologist and philosopher Henri Lefebvre (Aalbers \& Gibb, 2014).

\section{Housing and the right to the city}

'The right to the city' simply means that all urban dwellers have a right to belong and co-produce in the urban spaces that they belong too. Coined in 1968 by French sociologist and philosopher Henri Lefebvre and further popularized by David Harvey, 'the right to the city' is concept grounded on concrete social justice mandate ${ }^{13}$ as succinctly put forth by Lefebvre, "The real dimension is a concrete claim to integrated social, political and economic rights, the right to education, work, health, leisure and accommodation in an urban context that contributes to developing people and space rather than destroying or exploting people and space..." (Lefebvre, 1996) (cited in Aalbers \& Gibb, 2014). Simply put, Lefebvre is

13 Right to the City. Whose streets? Our streets! (Available at http://www.waronwant. org/righttothecity/) (accessed on 19 May 2015). 
approach injects 'social justice and inclusion' in the planning, production and consumption of urban places. He argues that continuous production and re-production of urban spaces should not happen at the expense of social space, and capitalism and the bureaucrats should be checked to see whether they have inadvertently created alienation and social exclusion instead of inculcating inclusiveness and habitable spaces for the original urban dwellers (Aalbers \& Gibb, 2014). This question itself is of particular relevance to Penang with rapid gentrification unfolding and the way housing is now being designed, constructed and marketed to match the means and desires of the rich. To exacerbate matters, many of these rich home buyers are foreigners who invest in highend properties in Penang but they will never call Penang their 'real home', let alone have a 'sense of belonging' or attachment with the island. Clearly, the presence and forces of alienation by foreigners have been set in motion in Penang's housing market. As an island, land in Penang is scarce and exorbitantly priced. Thus, dwelling and possessing properties on prime location matters. The next pertinent question that arises is the obsession that foreigners have with prime locations located in key urban areas of Penang, and how this alienating force is squeezing and displacing locales from their original urban settings.

"Location, location, location" is still a popular mantra in modern day real estate. Properties located in prime city locations are highly sought after because these properties will command and guarantee good returns whether rented out or resold in the market. This, of course, is irrefutable for Penang Island which is an island city with limited 'prime city locations' to offer. Price per square foot and rental are drastically (and artificially) bade up higher and higher by both the wealthy Penangites and foreigners to a breaking point where the marginalised, the working class and the poor are forced to evict from prime urban locations in inner city George Town. They are literally being 'priced out' and 'pushed out'. At this critical juncture, they not only lose their right to housing but they have also lost all their rights and entitlements to the city as well. As a result, they have been deterred and deprived of the opportunity to enjoy the provision and lifestyles that a city offers such as better physical infrastructures, amenities, job opportunities and transportation system. A critical question arises as to why local Penangites must give in to such forms of social injustice? Penang Island cannot be perceived as being holistically developed if a huge proportion of locales have to compete and contest for space with their foreign counterparts and ultimately lose out and fail to claim the right to their own city. The dire situation has also challenged all three core values purported by Sen (1999a. 1999b; see also Todaro \& Smith, 2011). In its current state, housing affordability (which is part of sustenance) is proving to be problematic for Penangites. Subsequently, the failure to possess their own houses will lead to the second value of self-esteem. Without a house to call their own, locals in Penang will have low self-esteem. And thirdly, as discussed above, Penang's poor, working class and even the 'new poor' category will no longer have the freedom to choose (Sen's third value) the type and location of housing they desire with the limited finances they have. The deprivation and inability to choose a proper shelter and being relegated as 'housing poor' will in one way or another hinder Penangites' capabilities to function fully and productively in the society.

\section{Conclusion and Implications}

Housing affordability woes are currently inflicting most nations and societies. It is one of the most pressing issues in the $21^{\text {st }}$ century. In this paper, housing affordability in Penang has been viewed and dissected from a development perspective based on Amartya Sen's three core development values as well as Lefebvre's right to the city in the context of housing. The discussions in this paper, however, pointed out that housing affordability in Penang Island is not aligned with these values where a huge fissure exists between the rich and the poor in terms of house ownership and affordability. Arguably, no matter how Penang Island might have progressed and developed in terms of having an expensive, high-end, luxurious and aesthetically-pleasing built environment, such manifestations of 
developed built environment is superficial and artificial when a huge proportion of low and middle-income islanders are still being deprived and denied of well-designed and conveniently located houses.

Therefore, conventional measurements of development and poverty are now being challenged because even Penangites with income levels above the National Poverty Line are now branded as the 'new poor' and they find it problematic, difficult and challenging to own decent and desired shelter on the island. Though alternative locations such as the mainland are viable options, the question that is being triggered has brought key concepts of development such as 'social justice,' 'inclusiveness' and a local Penangite's 'right to the city' to the forefront of discussion and policy debate. This paper advocates and recommends for a holistic development approach to be engaged when the State and private developers plan and develop new housing schemes on the island. Until and unless elements and values of development (as purported by Sen) are embraced in Penang Island's housing scenario, the tyranny of capitalism and urban neo-liberalism, as highlighted above, will continue to permeate and perpetuate the cycle of housing poverty and inequitable housing distribution on the island. If such as scenario is left to persist indefinitely, then clearly the future of Penang Island will be one that depicts a dire state of developed underdevelopment.

\section{References}

Aalbers, M. B., \& Gibb, K. (2014). Housing and the right to the city: Introduction to the special issue. International Journal of Housing Policy, 14(3), 207-213.

Australian Housing and Urban Research Institute (AHURI). (2005, May). Conceptualising and measuring the housing affordability problem. National Research Venture 3: Housing affordability for lower income Australians. Research Paper 1. Authors: Michelle Gabriel, Keith Jacobs, Kathy
Arthurson and Terry Burke with Judith Yates.

Australian Housing and Urban Research Institute (AHURI). (2007, September). Housing affordability: A $21^{\text {st }}$ century problem. National Research Venture 3: Housing affordability for lower income Australians. AHURI Final Report No. 105. Authors: Judith Yates and Vivienne Milligan with Mike Berry, Terry Burke, Michelle Gabriel, Peter Phibbs, Simon Sinnegar and Bill Randolph.

Bakhtyar, B., Zaharim, A., Sopian, K., \& Moghimi, S. (2013). Housing for poor people: A review on low cost housing process in Malaysia. WSEAS Transactions on Environment and Development, 2(9), 128-136.

Bassett, M., \& Malpass, L. (2013). Priced out. How New Zealand lost its housing affordability. Wellington: The New Zealand Initiative.

Briguglio, L. (1995). Small island developing states and their economic vulnerabilities. World Development, 23(9), 1615-1632.

Department of Statistics Malaysia. (2010). Migration Survey Report 2009. Putrajaya.

Evans, A.W., \& Hartwich, O. M. (2005). Unaffordable housing. Fables and myths. London: Policy Exchange Limited.

Gan, Q., \& Hill, R. J. (2009). Measuring housing affordability: Looking beyond the median. Journal of Housing Economics, 18, 115-125.

Gapor, S. A., Malek, N. M., \& Husin, A. (2011). Trends, problems and needs of urban housing in Malaysia. International Journal of Human and Social Sciences, World Academy of Science, Engineering and Technology, 74, 37-41.

Goh, B. L. (2010). Social justice and the Penang housing question. In Ooi Kee Beng \& Goh Ban Lee (Eds.). Pilot Studies for a new Penang. Penang Studies Series (147173). Singapore: ISEAS Publishing.

Government of Malaysia. (2015). Eleventh Malaysia Plan 2016 - 2020. Anchoring 
growth on people. Kuala Lumpur: Percetakan Nasional Malaysian Berhad.

Hashim, Z. A. (2010). House price and affordability in housing in Malaysia. Akademika, 78 (January - April), 37-46.

Housing Division, PSUKPP. (ND). Statistic on low cost and low medium cost housing ownership by district, Penang 2010. Retrieved from http://www.penang. gov.my/images/pdf/statistik\%20 sosioekonomi/8.\%20PERUMAHAN\% 20DAN\%20HARTANAH.pdf

Henry Butcher Malaysia (Penang). (2014) Penang real estate market research report Q1 2014. Henry Butcher Malaysia (Penang). Retrieved from www.henrybutcherpenang.com/upload files/621/HB\%20market\%20report.pdf

Khoo, S. L., Samat, N., Badarulzaman, N., \& Dawood, S. R. S. (2015). The promise and perils of the island city of George Town (Penang) as a Creative City, Urban Island Studies, 1(1), 20-34.

Malek, N. M., \& Husin, A. (2012). Pemilikan rumah dalam kalangan masyarakat bandar berpendapatan rendah dan sederhana di Malaysia (Translated: Homeownership among low- and middle-income urban dwellers in Malaysia), Sosio Humanika (Jurnal Pendidikan Sains Sosial dan Kemanusiaan), 5(2), Association of Indonesian Scholars of History Education.

Md. Sani, N. (2012). Affordable house In Kuala Lumpur, Malaysia. International Journal of Academic Research, 4(3), 75-82.

Miles, D. (2012). Demographics, house prices and mortgage design (No. 35). External MPC Unit Discussion Paper.

National Property Information Centre (NAPIC). Napic property sales data - Q3 2014. Retrieved from http:// napic.jpph.gov.my/portal/web/guest/ main-page?p_p_id = View Statistics_ WAR_ViewStatisticsportlet\&p_p_ lifecycle $=2 \& p \_p \_s t a t e=$ normal $\&$ p_p_ mode $=$ view $\& p_{-} p_{-}$resource i d = f i l e D o w n 1 o a d \& p _ p cacheability $=$ cacheLevelPage\&p_p_ $\mathrm{col}_{-} \mathrm{id}=\mathrm{column}-2 \& \mathrm{p}_{-} \mathrm{p}_{-} \mathrm{col}_{-}$ count $=2 \&$ _ViewStatistics_WAR_ ViewStatisticsportlet _action=renderAl 1CategoriesArc\&fileURI=3006

Peet, R., \& Hartwick, E. (2009). Theories of development. Contentions, arguments, alternatives (2nd Ed.). New York: The Guilford Press.

Penang Institute. (2011a, October). Supply and demand in the Penang housing market: Assessing affordability, Research Paper. Penang: Penang Institute.

Penang Institute. (2011b, October). Drivers of house price inflation in Penang, Malaysia: Planning a more sustainable future, Research Paper, Penang: Penang Institute.

Sen, A. (1999a). Commodities and capabilities. New Delhi: Oxford University Press.

Sen, A. (1999b). Development as freedom. New York: Anchor Books.

Shuid, S. (2010, July). Low income housing allocation system in Malaysia: Managing housing need for the poor. Paper presented during the $22^{\text {nd }}$ International Housing Research Conference, ENHR 2010. Turkey, Istanbul,

Socio-Economic Research Institute (SERI). (2010). Priced off Penang: Who can afford an island home? Penang: SERI. Retrieved from http://www.mymm2h. com/news/mm2h-in-news/598-pricedoff-penang-who-can-afford-an-islandhome.html

Soyza, M. (2013, September 13). Cover story: Experts' take on globalizing Malaysia properties. Business Times. Retrieved from http://www2.nst.com.my/business/latest/ cover-story-experts-take-on-globalisingmalaysian-properties-1.355021

Suhaida, M. S., Tawil, N. M., Hamzah, N., CheAni, A. I., \& Tahir, M. M. (2010). A conceptual overview of housing affordability in Selangor, Malaysia. International Journal of Social, Management, Economics and Business Engineering, 4(1), 408-410. 
Todaro, M. P., \& Smith, S. C. (2011). Economic development. (11 ${ }^{\text {th }}$ Ed.). England: Pearson Education Limited.

Turvey, R. (2007). Vulnerability assessment of developing countries: The case of smallisland developing states. Development Policy Review, 25(2), 243-264.
Van der Berg, S. (2008) Poverty and education. Education policy series. Joint publishers - Paris: The International Institute for Education Planning (IIEP) and Brussels: The International Academy of Education (IAE). 